OPEN ACCESS

Edited by:

Lie-Fen Shyur,

Academia Sinica,

Taiwan

Reviewed by:

Aline Carvalho Pereira,

Universidade Federal de Lavras,

Brazil

Souaibou Yaouba

Université de Lorraine, France

${ }^{*}$ Correspondence:

Minhui Li

prof_liminhui@yeah.net

Chunhong Zhang

zchlhh@126.com

Specialty section:

This article was submitted to

Ethnopharmacology,

a section of the journal

Frontiers in Pharmacology

Received: 20 September 2019

Accepted: 14 January 2020

Published: 07 February 2020

Citation:

Gong $X$, Wang J, Zhang $M$, Wang $P$,

Wang $C$, Shi $R$, Zang $E$, Zhang $M$,

Zhang C and Li M (2020) Bioactivity,

Compounds Isolated, Chemical

Qualitative, and Quantitative Analysis

of Cymbaria daurica Extracts.

Front. Pharmacol. 11:48.

doi: 10.3389/fphar.2020.00048

\section{Bioactivity, Compounds Isolated, Chemical Qualitative, and Quantitative Analysis of Cymbaria daurica Extracts}

\author{
Xue Gong ${ }^{1}$, Jie Wang ${ }^{1}$, Meiying Zhang ${ }^{1}$, Peng Wang ${ }^{2}$, Congcong Wang ${ }^{1}$, Ruyu Shi ${ }^{1}$, \\ Erhuan Zang ${ }^{1}$, Mingxu Zhang ${ }^{1}$, Chunhong Zhang ${ }^{1 *}$ and Minhui $L^{1,3,4,5 *}$ \\ ${ }^{1}$ Department of Pharmacy, Baotou Medical College, Baotou, China, ${ }^{2}$ Clinical Laboratory, The First Affiliated Hospital of \\ Baotou Medical College of Inner Mongolia University of Science and Technology, Baotou, China, ${ }^{3}$ Pharmaceutical \\ Laboratory, Inner Mongolia Autonomous Region Academy of Chinese Medicine, Hohhot, China, ${ }^{4}$ Guangxi Key Laboratory of \\ Medicinal Resources Protection and Genetic Improvement, Guangxi Botanical Garden of Medicinal Plants, Nanning, China, \\ 5 Inner Mongolia Key Laboratory of Characteristic Geoherbs Resources Protection and Utilization, Baotou Medical College, \\ Baotou, China
}

Cymbaria daurica L. is widely used in traditional Mongolian medicine for the treatment of impetigo, psoriasis, pruritus, fetotoxicity, and diabetes. Therefore, the anti-inflammatory and $\alpha$-glucosidase-inhibitory activities of four polar $C$. daurica extracts (water, n-butanol, ethyl acetate, and petroleum ether extract) were preliminarily evaluated to identify the active extracts. We also investigated the chemical composition of the active extracts by phytochemical analysis. The n-butanol and ethyl acetate extracts exhibited significant $(p<0.05)$ anti-inflammatory activities by inhibiting lipopolysaccharide-induced nitric oxide (NO) production in RAW 264.7 cells. None of the tested extracts exhibited cytotoxic effects at the effective concentrations. The ethyl acetate extract significantly inhibited $\alpha$-glucosidase activity, and the inhibition potency was equivalent to that of acarbose $(p>0.05)$. The $n$-Butanol extract presented the second highest inhibitory activity. As the n-butanol and ethyl acetate extracts were found to have potent antiinflammatory and $\alpha$-glucosidase-inhibitory activities, we separated and identified 10 compounds from the extracts. Among them, vanillic acid, cistanoside F, echinacoside, arenarioside, verbascoside, isoacteoside, and tricin were isolated from $C$. daurica for the first time. Further, 30 compounds from the n-butanol and ethyl acetate extracts of $C$. daurica were identified using UHPLC-Q-Exactive. The present study demonstrates for the first time that $C$. daurica contains phenylethanoid glycosides. In addition, this novel HPLC method was subsequently used for simultaneous identification of five compounds in the n-butanol and ethyl acetate extracts of $C$. daurica. This study provides a chemical basis for further characterization and utilization of $C$. daurica, which could be a potential source of novel anti-diabetic and anti-inflammatory agents.

Keywords: Cymbaria daurica L., Scrophulariaceae, anti-inflammatory activity, inhibition of $\alpha$-glucosidase activity, UHPLC-Q-Exactive Orbitrap HRMS, phenylethanoid glycoside, verbascoside 


\section{INTRODUCTION}

Mongolian medicines, which are being used for decades to manage various diseases (Zhang et al., 2015), have a history of more than 1,000 years, and Mongolians have developed their system of medicines based on their own culture and experience (Li et al., 2012). Treatment of diseases with Mongolian medicinederived compounds seems to be highly attractive because of their accessibility and ease of isolation (Zhang et al., 2015). Thus, Mongolian medicine is considered important in drug discovery. Furthermore, it has gradually gained interest as a valuable source of potential medicines.

Cymbaria daurica L. (Figure 1) belongs to the family Scrophulariaceae and is an important component of Mongolian medicines (Zhang et al., 2013). According to the Mengyaozhengdian, a complete and systematic Mongolian pharmaceutical classic of the 19th century, the whole plant is widely used in traditional Mongolian medicines for impetigo, psoriasis, pruritus, fetotoxicity, and diabetes (Health Department of Inner Mongolia Autonomous Region, 1987; Pharmacopoeia Committee of the Ministry of Health of the People's Republic of China, 1998; Zhang et al., 2013; Chang et al., 2015). In addition, C. daurica has anti-inflammatory, anti-bacterial, and antioxidant activities (Zhang et al., 2013; Hu, 2018). C. daurica has been extensively used in several classic herbal formulations recommended for anti-inflammation, such as Siweixinbasan and Baweixinbasan (Zhang et al., 2013; Liang et al., 2016). Some researchers have explored the pharmacological activities of $C$. daurica. The anti-inflammatory activities of $C$. daurica ethanol extracts have been reported in xylene-induced ear edema KM mice and egg white-induced paw edema SD rats. These studies revealed that $C$. daurica ethanol extract could restrain ear edema in mice and paw edema in rats at $6 \mathrm{~h}$ after egg whiteinduced inflammation (Guo et al., 2017). Chang et al. (2015) showed that the water and n-butanol extracts of $C$. daurica significantly reduced glucose levels in alloxan-induced diabetic mice. However, there are only a few phytopharmacological studies on $C$. daurica. The main pharmacological activities of C. daurica can be attributed to the different bioactive compounds previously reported in this traditional plant (Amessis-
Ouchemoukh et al., 2014). However, the chemical composition of C. daurica is not entirely clear (Li et al., 2014).

Therefore, to validate the therapeutic effects of $C$. daurica, we investigated the anti-inflammatory and $\alpha$-glucosidase-inhibitory activities of various extracts (water extract, n-butanol extract, ethyl acetate extract, and petroleum ether extract) of $C$. daurica to identify the active extracts. Next, the compounds were separated from the active extracts. Combined with the results of previous phytochemical research (Li et al., 2014; Bai et al., 2018), a database of $C$. daurica compounds was constructed; the chemical composition of the extracts was analyzed by UHPLCQ-Exactive. In addition, the components with a high content and potential activity in $C$. daurica were simultaneously determined using a novel high-performance liquid chromatography (HPLC) method.

\section{MATERIALS AND METHODS}

\section{Materials \\ Plant Material}

C. daurica was collected in grassland $\left(44^{\circ} 34^{\prime} 5.8^{\prime \prime} \mathrm{N}, 117^{\circ} 35^{\prime} 6.7^{\prime \prime}\right.$

E, Elevation: $1058.9 \mathrm{~m}$ ), Haoletugaole Town, West Ujimqin Banner, XilinGol League, Inner Mongolia Autonomous Region in June 2018 and was authenticated by Life Science Faculty, Inner Mongolia University. Furthermore, voucher specimen of the same was deposited in the Herbarium of HIMC (Specimen No.: 152500180629025LY) for future reference.

\section{Cells and Reagents}

Raw 264.7 cell line was purchased from the Cell Bank in the China Academy of Science (Shanghai, China). High glucose Dulbecco's modified Eagle medium (DMEM) (Gibco, USA), fetal bovine serum (FBS), penicillin and streptomycin (HyClone, Thermo Scientific), phosphate-buffered saline (PBS), dimethyl sulfoxide (DMSO), lipopolysaccharide (Sigma, USA), and indomethacin (TMstandard, USA) were purchased from Sino-American Biotechnology Company (Beijing, China); ultrapure water was obtained from Gen Pure (Thermo, USA).
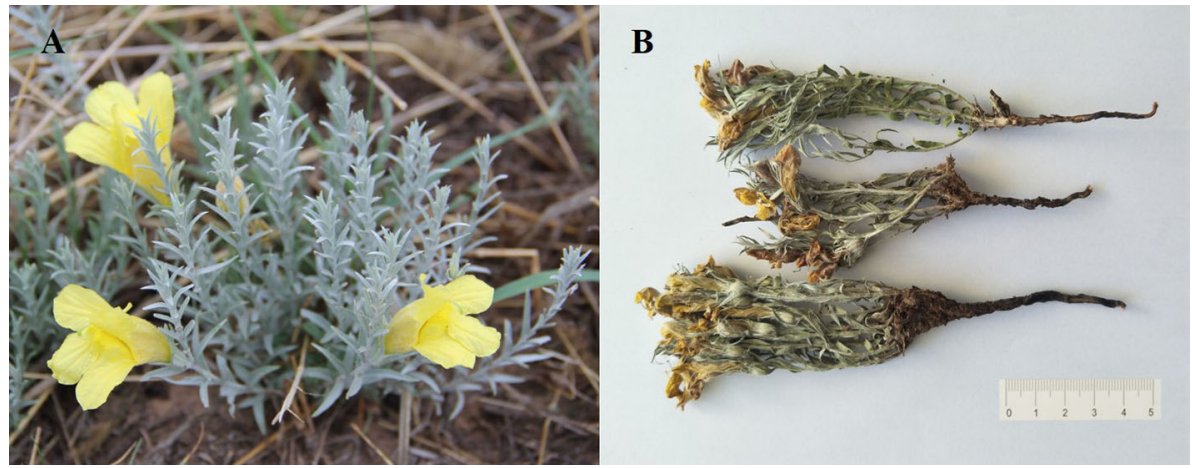

FIGURE 1 | Images of Cymbaria daurica from aerial parts of $C$. daurica (A) and the whole plant of C. daurica (B). 
3-(4,5-Dimethylthiazol-2-yl)-2,5-diphenyltetrazolium bromide (MTT) and dimethyl sulfoxide (DMSO) were purchased from Sangon Biotech (Shanghai, China). The Nitric Oxide (NO) Assay kit was purchased from Nanjing Jiancheng Bioengineering Institute (Nanjing, China). $p$-Nitrophenol $\alpha$-D-glycopyranoside (pNPG) and $\alpha$-glucosidase (EC 3.2.20, from Saccharomyces cerevisiae, lyophilized powder) were obtained from Sigma (USA).

\section{Chemicals and Reagents}

Acetonitrile (HPLC grade) was purchased from Fisher Scientific (Fisher Scientific, USA). Purified water was obtained using a Milli-Q system (Millipore, USA). All other reagents were of analytical grade. The reference compounds of 18 analytes were purchased from the National Institute for the Control of Pharmaceutical and Biological Products (Beijing, China).

\section{Methods}

\section{Extraction and Processing}

Dried whole-plant powder of C. daurica $(1.45 \mathrm{~kg})$ was extracted successively with $70 \%$ ethanol to produce $362.5 \mathrm{~g}$ of extract. The extract was dissolved in water, and then extracted successively with petroleum ether, ethyl acetate, and n-butanol to produce $55.91,21.47$, and $110.77 \mathrm{~g}$ of dry extract, respectively. The aqueous phase contained $174.26 \mathrm{~g}$ of the residue.

\section{Anti-Inflammatory Assay Cell Culture}

RAW 264.7 mouse macrophages were cultured in high glucose DMEM supplemented with $10 \%$ FBS and a mixture of penicillin and streptomycin. The cells were maintained in a humidified incubator with an atmosphere of $5 \% \mathrm{CO}_{2}$ at $37^{\circ} \mathrm{C}$.

\section{Cell Viability Assay}

The MTT assay was used to assess whether $C$. daurica extracts exerted cytoprotective effects on RAW 264.7 cells. RAW 264.7 cells were seeded in a 96-well plate at a density of $1 \times 10^{5}$ cells/ $\mathrm{mL}$, cultured for $24 \mathrm{~h}$, and then divided into control and treatment groups. The four extracts of $C$. daurica were dissolved in DMSO $(<0.01 \%)$ and diluted with complete culture medium. The treatment cell groups were pretreated with vehicle alone or with different concentrations $(25,50,100$, $200,400,800,1,600$, and $3,200 \mu \mathrm{g} / \mathrm{mL}$ ) of C. daurica extracts (water, n-butanol, ethyl acetate, and petroleum-ether extracts) for $24 \mathrm{~h}$. The cells were then incubated with $10 \mu \mathrm{L}$ of MTT solution for $4 \mathrm{~h}$ at $37^{\circ} \mathrm{C}$, after which the supernatant was discarded and $150 \mu \mathrm{L}$ of DMSO was added to each well. The plates were oscillated at a low speed for $5 \mathrm{~min}$ at room temperature until all the formed crystals were fully dissolved. Optical density was determined at an absorbance wavelength of $570 \mathrm{~nm}$ (Thermo Scientific Multiskan FC, Thermo, USA). The optical density of the control (untreated) cells was designated as $100 \%$ viability.

\section{Nitric Oxide Assay}

RAW 264.7 cells were plated at a density of $5 \times 10^{5}$ cells $/ \mathrm{mL}$ in 24-well plates, cultured for $12 \mathrm{~h}$, and then treated with LPS $(1 \mu \mathrm{g} /$ $\mathrm{mL}$ ) and incubated for $4 \mathrm{~h}$. Thereafter, the cells were treated with different concentrations $(25,50,100,200$, and $400 \mu \mathrm{g} / \mathrm{mL})$ of $C$. daurica extracts (water, n-butanol, ethyl acetate, and petroleumether extracts) and incubated for an additional $20 \mathrm{~h}$. Meanwhile, the negative control groups were treated for $20 \mathrm{~h}$ with $400 \mu \mathrm{g} / \mathrm{mL}$ of each extract, but not with LPS. Indomethacin $(6.25,12.5,25$, 50 , and $100 \mu \mathrm{M}$ ) was used as the positive control (Cheng et al., 2017). The amount of NO in the medium was detected using the Griess test. One hundred microliters of each supernatant were mixed with equal volume of Griess reagent (1\% sulfanilamide in $5 \%$ phosphoric acid and $0.1 \%$ naphthylethylenediamine dihydrochloride in water). The absorbance of the mixture at $550 \mathrm{~nm}$ and concentration of nitrite were determined using serially diluted sodium nitrite as the standard (Qiao et al., 2005).

\section{$\alpha$-Glucosidase Inhibition Assay}

We examined whether the four $C$. daurica extracts could inhibit the activity of $\alpha$-glucosidase using a previously published method (Schmidt et al., 2014). Briefly, each extract of $C$. daurica was dissolved in DMSO $(<0.05 \%)$, and then diluted with phosphate buffer ( $\mathrm{pH}$ 6.9). Then, $20 \mu \mathrm{L}$ of each extract (at a concentration of $50,75,100,125$, or $150 \mu \mathrm{g} / \mathrm{mL}$ ) was added into a 96-well microplate. Next, $10 \mu \mathrm{L}$ of $\alpha$-glucosidase from Saccharomyces, $10 \mu \mathrm{L}$ of $3 \mu \mathrm{M}$ glutathione, and $20 \mu \mathrm{L}$ of phosphate buffer were added to each well, and the plate was incubated at $37^{\circ} \mathrm{C}$ for $10 \mathrm{~min}$. Thereafter, $20 \mu \mathrm{L}$ of $0.01 \mathrm{M} \mathrm{p}$ nitrophenyl glucopyranoside (pNPG) was added to each well to quench the reaction, and the plate was incubated at $37^{\circ} \mathrm{C}$ for 20 min. The reaction was stopped by the addition of $100 \mu \mathrm{L}$ of $0.1 \mathrm{M}$ $\mathrm{Na}_{2} \mathrm{CO}_{3}$ into each well, and the absorbance was recorded at 405 $\mathrm{nm}$. The control sample contained buffer instead of $\alpha$ glucosidase. Acarbose was used as the positive control.

\section{Isolation of Pure Compounds}

The n-butanol extract (25 g) was fractionated on a D101 macroporous resin column using EtOH- $\mathrm{H}_{2} \mathrm{O}$ (70:30) to obtain 15 fractions, and then by TLC to obtain four main fractions (Frs. A1-A4). Fr. A1 was recrystallized repeatedly (MeOH-EtOH) to obtain compound 1 (57.9 mg). Fr. A2 was further purified via repeated chromatography on Sephadex LH-20 to obtain compound $2(11.3 \mathrm{mg})$. Fr. A3 was further purified by chromatography on an ODS column $\left(\mathrm{MeOH}-\mathrm{H}_{2} \mathrm{O}, 0: 100-\right.$ 20:80) to obtain four fractions (Frs. B1-B4). Fr. B1 was further purified by repeated chromatography on silica gel to obtain compound 3 (25.4 mg). Fr. B2 was further purified by chromatography on an $\mathrm{MCI}$ column $\left(\mathrm{MeOH}-\mathrm{H}_{2} \mathrm{O}\right.$, gradient elution) to obtain compound $4(14.0 \mathrm{mg})$. Fr. B3 was further purified by repeated chromatography on Sephadex LH-20 to obtain compound 5 (16.6 mg). Fr. B4 was further purified by repeated chromatography on Sephadex LH-20 to obtain compound $6(27.0 \mathrm{mg})$. Fr. A4 was further purified by chromatography on an ODS column $\left(\mathrm{MeOH}-\mathrm{H}_{2} \mathrm{O}(30: 70-\right.$ 70:30) to obtain seven fractions (Frs. C1-C7). Combined Fr. C4 was further purified by repeated chromatography on Sephadex LH-20 (MeOH- $\left.\mathrm{H}_{2} \mathrm{O}, 70: 30\right)$ to obtain compounds 7 (119.9 $\mathrm{mg}$ ) and 8 (19.8 $\mathrm{mg})$.

Ethyl acetate extract (17 g) was fractionated on a D101 macroporous resin column using EtOH- $\mathrm{H}_{2} \mathrm{O}$ (70:30) to obtain 
10 main fractions (Frs. D1-D10) [10]. Frs. D4-D7 was further purified by chromatography on an ODS column $\left(\mathrm{MeOH}-\mathrm{H}_{2} \mathrm{O}\right.$, 30:70-70:30) to obtain seven fractions (Frs. E1-E7). Combined Fr. E4 was further purified by repeated chromatography on Sephadex $\mathrm{LH}-20\left(\mathrm{MeOH}-\mathrm{H}_{2} \mathrm{O}, 70: 30\right)$ to obtain compounds 7 (74.0 mg) and 8 (22.0 mg). Frs. D8-D9 was further purified by chromatography on silica gel $\left(\mathrm{CHCl}_{3}-\mathrm{MeOH}, 90: 10-60: 40\right)$ to obtain 12 fractions (Frs. F1-12). Combined Frs. F2-F6 was further purified by repeated chromatography on Sephadex LH$20\left(\mathrm{MeOH}-\mathrm{H}_{2} \mathrm{O}, 80: 20\right)$ to obtain compounds $9(20.4 \mathrm{mg})$ and $10(23.7 \mathrm{mg})$.

\section{HPLC-MS}

\section{HPLC-MS/MS System and Operating Conditions}

The Thermo Scientific ${ }^{\mathrm{TM}}$ Ultimate $^{\mathrm{TM}} 3000$ RS system was used in this assay. Chromatographic separation was performed on the Hypersil GOLD $\mathrm{C}_{18}(100 \mathrm{~mm} \times 2.1 \mathrm{~mm}, 3 \mu \mathrm{m}$; Thermo Scientific) column. Acetonitrile (solvent B) and water (containing $0.1 \%$ formic acid, solvent $\mathrm{A}$ ) were used as the mobile phase. The gradient was as follows: $0-35 \mathrm{~min}, 5 \%-60 \%$ B. The flow rate was $0.3 \mathrm{~mL} / \mathrm{min}$.

Mass spectrometry data were acquired using the Q Exactive High-Resolution Benchtop Quadrupole Orbitrap Mass Spectrometer (Thermo Fisher Scientific, USA) equipped with an ESI interface in the positive and negative ion modes. Optimal parameters were as follows: probe heater temperature, $350^{\circ} \mathrm{C}$; spray voltage, $3.5 \mathrm{kV}$ for the positive and negative ion modes; sheath gas, 35 arb; auxiliary gas, 10 arb. Capillary temperature was set at $320^{\circ} \mathrm{C}$ and S-lens was $50 \mathrm{~V}$. Full-scan MS data were generated across a mass range of 100-1500 Da. The stepped normalized collision energy setting was 20, 40, and $60 \mathrm{eV}$. All MS spectra were acquired using the Q Exactive Mass Spectrometer controlled using Xcalibur 3.0 software (Thermo Fisher Scientific).

\section{Data Processing}

MS data were processed using QualBrowser of Xcalibur 3.0 software (Thermo Fisher Scientific), and they included extracted ion chromatograms, fragmentation behavior, and elemental compositions with mass errors within $5 \mathrm{ppm}$. All analytes were identified using their elemental composition, accurate mass measurement, elution order, fragmentation behavior, fragmentation pattern of the standard compound, and comparison with reliable data in compounds database (Wang et al., 2018).

\section{HPLC Analysis}

The nucleosil C18 column $(4.6 \mathrm{~mm} \times 250 \mathrm{~mm}, 5 \mu \mathrm{m}$; Agilent $)$ was used for the analysis of catalpol, verbascoside, isoacteoside, luteolin, and apigenin by HPLC. The mobile phase consisted of water (containing $0.1 \%$ phosphoric acid, solvent A) and acetonitrile (solvent $\mathrm{B}$ ). The gradient was as follows: $0-15 \mathrm{~min}$, $1 \% \mathrm{~B} ; 15-25 \mathrm{~min}, 1-15 \% \mathrm{~B} ; 25-70 \mathrm{~min}, 15-35 \% \mathrm{~B} ; 70-75 \mathrm{~min}$, $35-50 \% \mathrm{~B}$. The flow rate was $1 \mathrm{~mL} / \mathrm{min}$. Injection volume was 10 $\mu \mathrm{L}$, and the temperature of the column was maintained constant at $30^{\circ} \mathrm{C}$. Detection was performed using at wavelengths of 210 , 330, and $365 \mathrm{~nm}$. The n-butanol and ethyl acetate extracts of $C$. daurica were analyzed by HPLC. Each sample was assayed in triplicate. Chromatographic peaks of the samples were quantified via external standard method. The HPLC method developed in this study was validated for linearity, precision, repeatability, and stability.

\section{Statistical Analysis}

All data were analyzed using SPSS 19.0, and the results are presented as mean \pm standard deviation $(\mathrm{SD})$ of three independent experiments. Values with $p<0.05$ were considered significantly different.

\section{RESULTS}

\section{Anti-Inflammatory Assay Effect of the Four C. daurica Extracts on the Viability of RAW 264.7 Cells}

RAW 264.7 cells, pretreated for $24 \mathrm{~h}$ with five different concentrations $(25,50,100,200$, and $400 \mu \mathrm{g} / \mathrm{mL})$ of the water, n-butanol, ethyl acetate, and petroleum-ether extracts showed no significant differences in cell viability compared with that of the control group $(p>0.05)$ (Figure 2). However, pretreatment with $800,1,600$, or $3,200 \mu \mathrm{g} / \mathrm{mL}$ of the water, n-butanol, ethyl acetate, or petroleum-ether extract significantly decreased cell activity ( $p$ $<0.01$ ). These results indicate that pretreatment of RAW 264.7 cells with the four $C$. daurica extracts at concentrations of 25, 50, 100,200 , and $400 \mu \mathrm{g} / \mathrm{mL}$ did not result in cytotoxicity; therefore, these concentrations were selected for further experiments.

\section{Effect of Extracts From Four Parts of C. daurica on RAW 264.7 Cell NO Production}

As shown in Figure 3, RAW 264.7 cells did not release NO in response to the culture medium. In this study, LPS was used to activate RAW 264.7 cells. NO production by RAW 264.7 cells stimulated with LPS $(1 \mu \mathrm{g} / \mathrm{mL})$ was significantly increased compared with that of the control group $(p>0.001)$. When used separately, the four extracts of $C$. daurica $(400 \mu \mathrm{g} / \mathrm{mL})$ did not affect NO production in RAW 264.7 cells $(p>0.05)$. However, when different concentrations of n-butanol and ethyl acetate extracts (25, $50,100,200$, and $400 \mu \mathrm{g} / \mathrm{mL}$ ) were added to the culture media during cell stimulation $(20 \mathrm{~h})$, NO production was inhibited in a dose-dependent manner $(p<0.05$, Figures 3B, C). The n-butanol and ethyl acetate extracts exhibited significant anti-inflammatory activity with the $\mathrm{IC}_{50}$ values of $197.00 \pm 0.74$ and $90.00 \pm 1.05 \mu \mathrm{g} /$ $\mathrm{mL}$, respectively, whereas, indomethacin, as the positive control, had an $\mathrm{IC}_{50}$ of $59.97 \pm 0.80 \mu \mathrm{M}$ (Table 1). However, the water and petroleum-ether extracts did not inhibit LPS-induced NO production and did not exhibit anti-inflammatory activity (Figures 3A, D). These results suggest that the extracts of $C$. daurica may function, at least partially, via macrophage activation in the host defense response.

\section{$\alpha$-Glucosidase Inhibition}

To the best of our knowledge, this is the first study to report that the extracts of $C$. daurica can inhibit the activity of $\alpha$-glucosidase. The results of the effects of $C$. daurica extracts on $\alpha$-glucosidase 

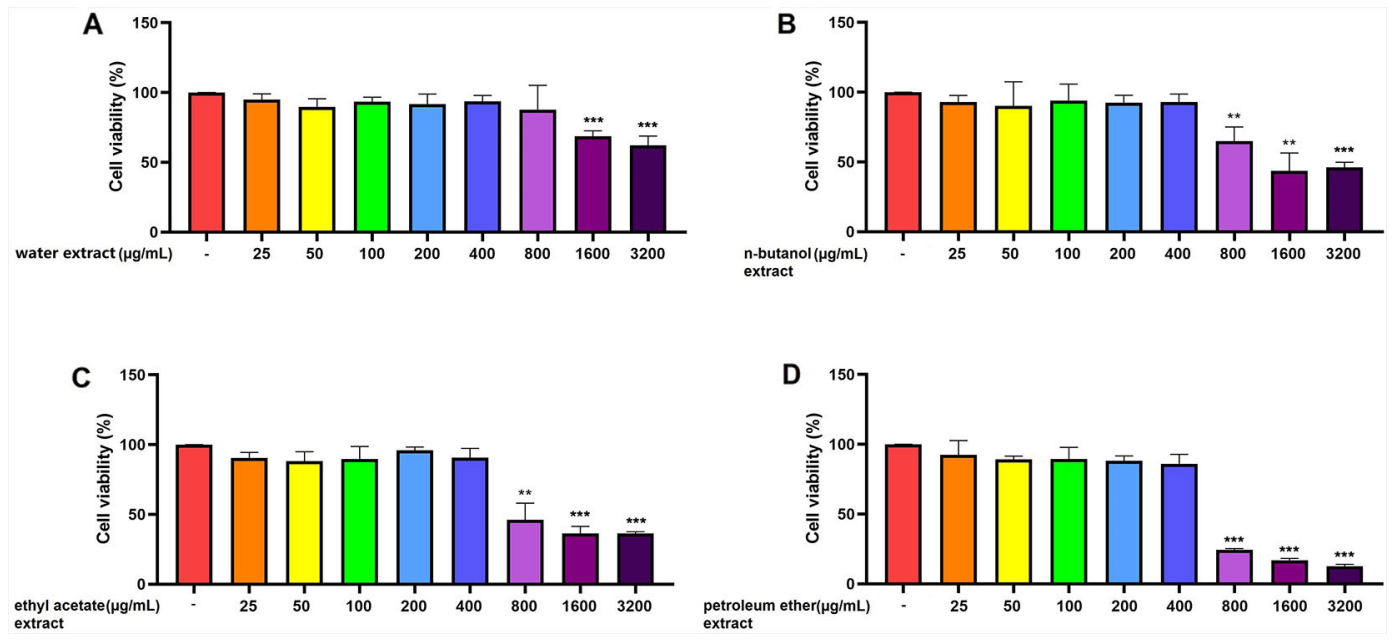

FIGURE 2 | Effect of the four C. daurica extracts on viability of RAW 264.7 cells. (A) water extract. (B) n-butanol extract. (C) ethyl acetate extract. (D) petroleum ether extract. Data are presented as means $\pm \mathrm{SD}, n=5 .{ }^{\star \star} p<0.01,{ }^{\star \star \star} p<0.001$ compared with control.
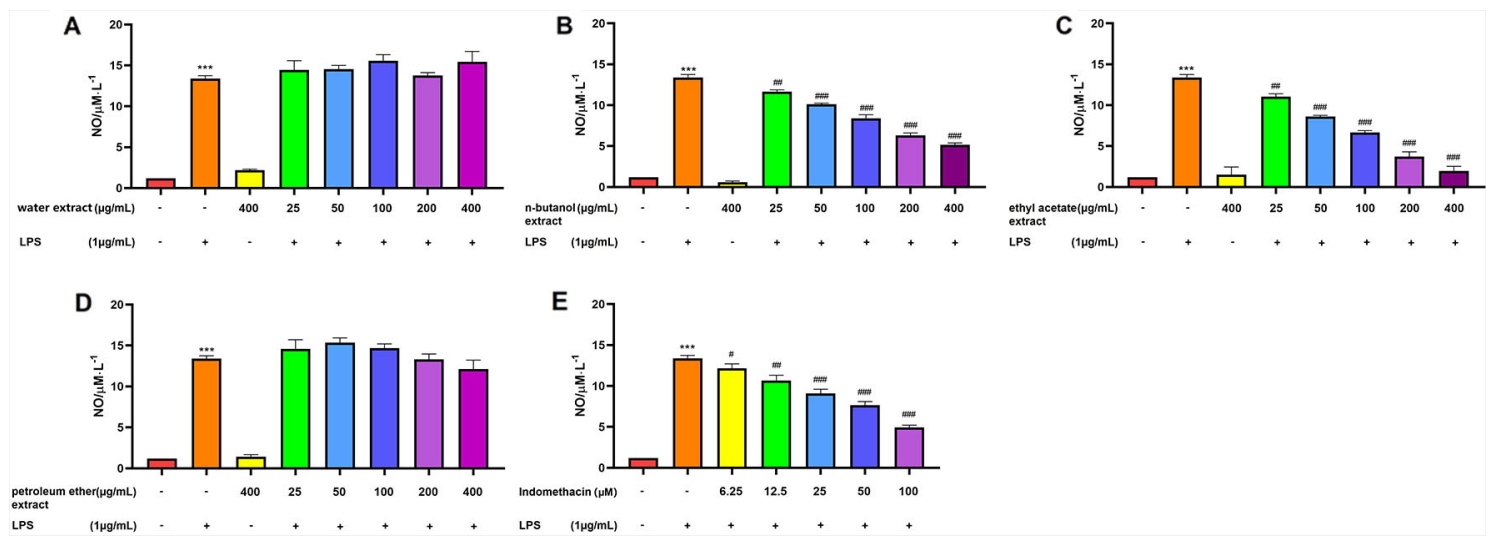

FIGURE 3 | Effect of extracts from four parts of the C. daurica on LPS-induced NO production in RAW 264.7 cell. (A) water extract. (B) n-butanol extract. (C) ethyl acetate extract. (D) petroleum ether extract. (E) indomethacin. Data are presented as means \pm SD, $n=5 .{ }^{\star \star \star *} p<0.001$ compared with control; \#\#\# $p<0.001$, \#\# $p<$ $0.01, "{ }^{\#} p<0.05$ compared with LPS. (Control group; Model group: LPS; Negative control group: water extract, n-butanol extract, ethyl acetate extract, petroleum ether extract; Treated group: water extract + LPS, n-butanol extract + LPS, ethyl acetate extract + LPS, petroleum ether extract + LPS).

TABLE $1 \mid I C_{50}$ values $(\mu \mathrm{g} / \mathrm{mL})$ of inhibitory activities of $C$. daurica extracts on LPS-induced NO production in RAW264.7 cell. $(n=5, x \pm s)$.

\begin{tabular}{llc}
\hline Source & \multicolumn{1}{c}{ Extract fractions } & IC $_{\mathbf{5 0}}$ \\
\hline C. daurica & Water extract & - \\
& n-butanol extract & $197.00 \pm 0.74$ \\
& Ethyl acetate extract & $90.00 \pm 1.05$ \\
Indomethacin $^{\text {a }}$ & Petroleum ether extract & - \\
& - & $59.97 \pm 0.80^{\text {b }}$
\end{tabular}

andomethacin was used as positive control.

${ }^{b}$ The concentration units were $\mu \mathrm{M}$. activity are presented in Table 2. As shown in Table 2, the water, n-butanol, ethyl acetate, and petroleum-ether extracts of $C$. daurica exerted inhibitory activity on the activity of $\alpha$-glucosidase $\left(\mathrm{IC}_{50}=\right.$ $175.8 \pm 2.11,133.2 \pm 2.59,105.9 \pm 0.89$, and $173.6 \pm 1.11 \mu \mathrm{g} / \mathrm{mL}$, respectively). Among the four extracts of $C$. daurica, ethyl acetate extract exerted significant inhibitory effects on $\alpha$-glucosidase, showing an $\mathrm{IC}_{50}$ of $105.9 \pm 0.89 \mu \mathrm{g} / \mathrm{mL}$; the $\alpha$-glucosidaseinhibition potency was equivalent to that of acarbose (108.2 \pm $1.28 \mu \mathrm{g} / \mathrm{mL}, p>0.05)$. These results show that $C$. daurica extracts can be used to design new plant-based drugs and nutraceuticals. 
TABLE 2||$C_{50}$ values $(\mu \mathrm{g} / \mathrm{mL})$ of $\alpha$-glucosidase inhibition activity of $C$. daurica extracts. ( $n=3, x \pm s)$.

\begin{tabular}{llr}
\hline Source & \multicolumn{1}{c}{ Extract fractions } & \multicolumn{1}{c}{$\mathbf{I C}_{\mathbf{5 0}}$} \\
\hline C. daurica & Water extract & $175.8 \pm 2.11$ \\
& n-butanol extract & $133.2 \pm 2.59$ \\
& Ethyl acetate extract & $105.9 \pm 0.89$ \\
Acarbose & Petroleum ether extract & $173.6 \pm 1.11$ \\
& - & $108.2 \pm 1.28$ \\
\hline
\end{tabular}

\section{Isolation of Pure Compounds}

The n-butanol and ethyl acetate extracts showed considerable anti-inflammatory and $\alpha$-glucosidase-inhibitory activities. Furthermore, we conducted phytochemical analysis of the nbutanol and ethyl acetate extracts from $C$. daurica. We isolated compounds $1,2,3,4,5,6,7$, and 8 from the n-butanol extract. Compounds 7, 8, 9, and 10 were isolated from the ethyl acetate extract. The structure of these compounds was identified by comparing their spectral data (obtained via proton nuclear magnetic resonance $\left[{ }^{1} \mathrm{H}-\mathrm{NMR},{ }^{13} \mathrm{C}-\mathrm{NMR}\right]$ (the spectral data of compounds 1-10 are shown in Supplemental Material), and electrospray ionization [ESI-MS]) with published data on catalpol (1) (Nguyen et al., 2005), vanillic acid (2) (Chen et al., 2011), ajugol (3) (Zhang et al., 2016a), cistanoside F (4) (Liu et al., 2016), echinacoside (5) (Zhen and Shi, 2004), arenarioside (6) (Andary et al., 1985), verbascoside (7) (Wu et al., 2012), isoacteoside (8) (Liu et al., 2011), apigenin (9) (Chu et al., 2014), and tricin (10) (Han et al., 2013). The chemical structure of the 10 compounds is shown in Figure 4. Our study is the first to isolate compounds 2, 4, 5, 6, 7, 8 , and 10 from C. daurica. Furthermore, this is the also first report of phenylethanoloside compounds found in C. daurica.

\section{HPLC-MS Analysis}

We examined the chemical composition of $C$. daurica. Chemical composition of the n-butanol and ethyl acetate extracts of $C$. daurica was determined by UHPLC-Q-Exactive. To determine the chemical composition, we evaluated the retention time, ionic species, and major fragments in MS and $\mathrm{MS}^{2}$ spectra. We also searched an online database and literature, and examined fragmentation patterns of standard compounds. Based on these analyses, the chemical structure of the n-butanol and ethyl acetate extracts of $C$. daurica was tentatively identified and classified into four major groups, namely, phenylethanoid glycosides, flavonoids, iridoids, and phenolic acids. The total ion chromatograms of $\mathrm{n}$ butanol and ethyl acetate extracts of $C$. daurica, both in the negative ion mode, are presented in Figure 5. Retention time, molecular formula, theoretical mass, and measured mass of the 30 identified compounds are presented in Table 3.

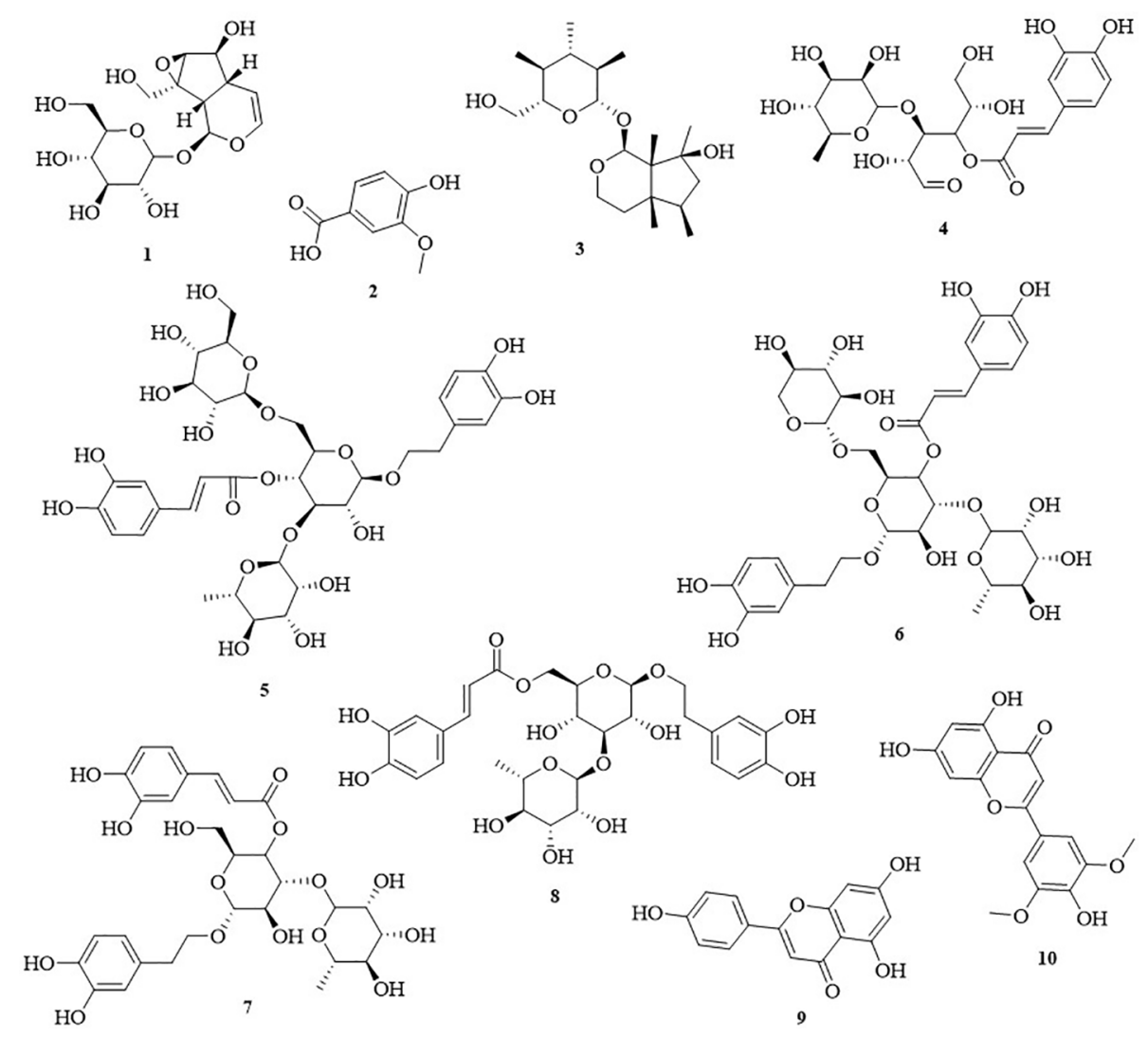

FIGURE 4 | The chemical structures of ten monomeric compounds. 1 catalpol; 2 vanillic acid; 3 ajugol; 4 cistanoside F; 5 echinacoside; 6 arenarioside; 7 verbascoside; 8 isoacteoside; 9 apigenin; 10 tricin. 

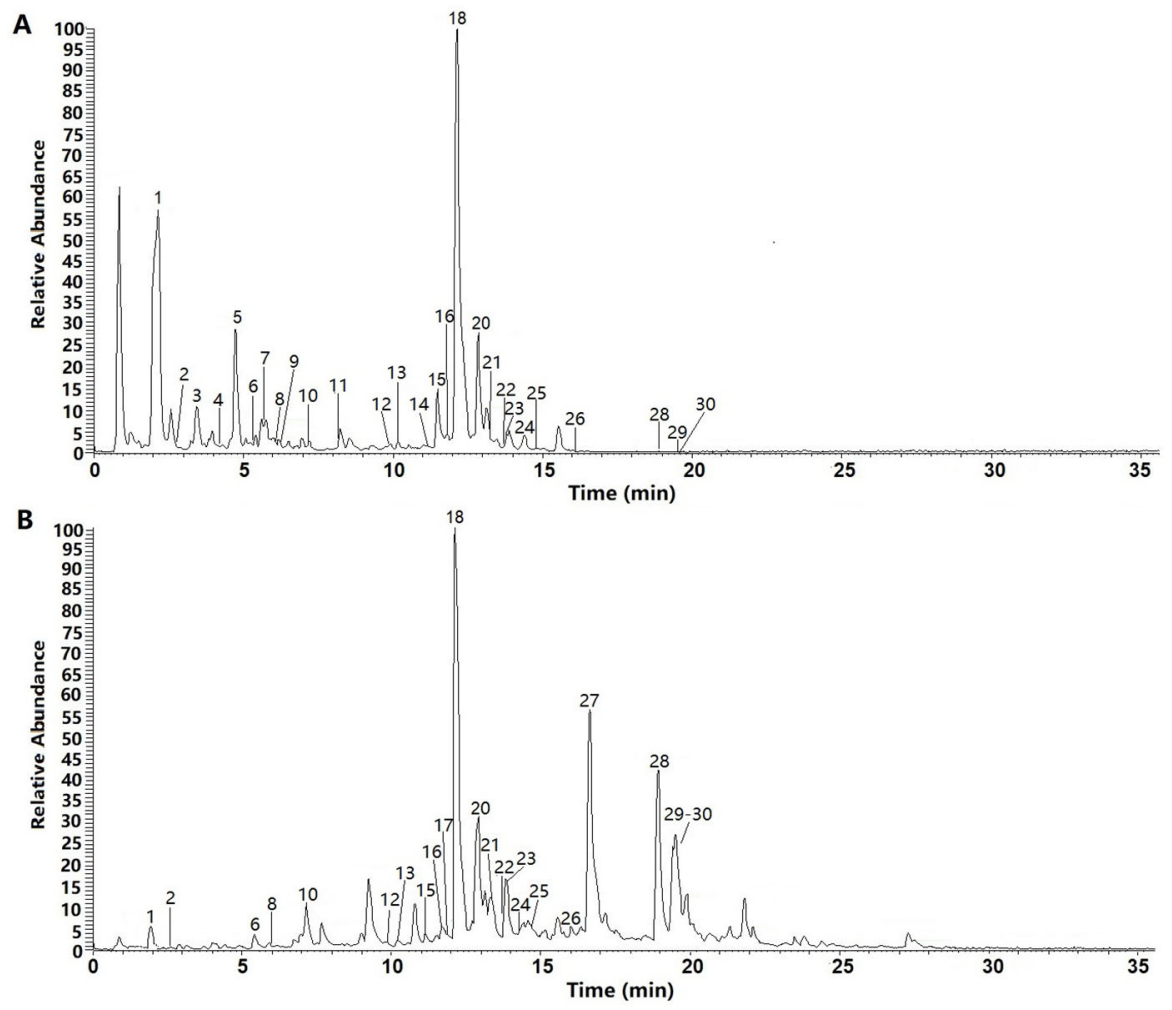

FIGURE 5 | The total ion chromatograms (TIC) of n-butanol extract (A) and ethyl acetate extract (B) form the C. daurica in negative mode.

Individual compounds in the n-butanol and ethyl acetate extracts of $C$. daurica were characterized as follows. Peak 1 in the n-butanol and ethyl acetate extracts was observed at $m / z 361$. According to Song et al. (2016), peak 1 was characterized as catalpol, consistent with the fragmentation pattern of the standard compound. Based on MS, MS/MS data, data found in the literature (Song et al., 2016), and comparison with fragmentation patterns of the standard compounds, vanillic acid (peak 4) was detected in the n-butanol extract of $C$. daurica. Vanillic acid showed fragments at $m / z 167,151$, and 107. Peak 18, at $m / z$ 623, was identified as verbascoside because it showed fragments at $\mathrm{m} / z 461$ and 161 . This fragmentation pattern was consistent with that of the standard compound, as well as patterns reported in previous studies (Song et al., 2016; Zhang et al., 2016b). Peak 20 also showed similar fragmentation pattern and was proposed to be a verbascoside isomer. Based on comparison with fragmentation pattern of the standard compound, Peak 20 was identified as isoacteoside. Peak 29, with $m / z 329$, was proposed to be tricin and showed fragments of $m / z 314,162$, and 151 in the MS/MS spectrum. These $\mathrm{MS}^{2}$ data matched the fragmentation pattern of the standard compound.

Aucubin, caffeic acid, rutin, cynaroside, catalpol echinacoside, and apigenin, previously reported as present in $C$. daurica, show strong anti-inflammatory and hypoglycemic activities (Sun et al., 2004; Li, 2013; Dong and Chen, 2013; Han et al., 2017; Li et al.,
2017; Yang et al., 2017; Bao et al., 2018), whereas vanillic acid, luteolin, verbascoside, and tricin show considerable antiinflammatory activity (Jeong et al., 2017; Yin et al., 2017; Li et al., 2018a; Li et al., 2018b).

\section{HPLC Analysis}

Based on the biological activity and chemical composition of the n-butanol and ethyl acetate extracts, identified by HPLC-MS, we developed a novel HPLC method for simultaneous identification of five compounds with high content and potential activity. A sample chromatogram is shown in Figure 6. As illustrated in Figure 6, the five compounds were well separated under the described chromatographic conditions. As shown in Table 4, all calibration curves exhibited excellent linearity $\left(R^{2}=0.9991-\right.$ 0.9998 ) in a relatively wide concentration range. This method was validated for precision, repeatability, and stability, as shown in Table 5. These results show that the HPLC method, developed in this study, was precise, accurate, and sensitive enough for simultaneous quantitative evaluation of five compounds in $C$. daurica. This novel HPLC method was subsequently used for simultaneous identification of five compounds in the n-butanol and ethyl acetate extracts of C. daurica. As shown in Table 6, the content of each compound varied depending on the extract; for example, the content of verbascoside in the n-butanol extract and that in 
TABLE 3 | Identification of major chemical constituents in n-butanol extract and ethyl acetate extract form the $C$. daurica.

\begin{tabular}{|c|c|c|c|c|c|c|c|c|}
\hline \multirow[t]{2}{*}{ Peak } & \multirow[t]{2}{*}{ Compounds } & \multirow[t]{2}{*}{ Formula } & \multirow[t]{2}{*}{ Ion mode } & \multirow[t]{2}{*}{ Theoretical $(m / z)$} & \multicolumn{2}{|c|}{ n-butanol extract } & \multicolumn{2}{|c|}{ Ethyl acetate extract } \\
\hline & & & & & RT (min) & Measured $(m / z)$ & RT (min) & Measured $(\mathrm{m} / \mathrm{z})$ \\
\hline 1 & Catalpol $^{\star}$ & $\mathrm{C}_{15} \mathrm{H}_{22} \mathrm{O}_{10}$ & Negative & 361.11402 & 2.15 & 361.11423 & 2.00 & 361.11420 \\
\hline 2 & Isoxepac glucuronide & $\mathrm{C}_{22} \mathrm{H}_{20} \mathrm{O}_{10}$ & Negative & 443.09837 & 2.58 & 443.09638 & 2.56 & 443.24743 \\
\hline 3 & Aucubin* & $\mathrm{C}_{15} \mathrm{H}_{22} \mathrm{O}_{9}$ & Negative & 345.11910 & 3.48 & 345.11911 & - & - \\
\hline 4 & Vanillic acid* & $\mathrm{C}_{8} \mathrm{H}_{8} \mathrm{O}_{4}$ & Negative & 167.03498 & 4.29 & 167.03422 & - & - \\
\hline 5 & Ajugol* $^{*}$ & $\mathrm{C}_{15} \mathrm{H}_{24} \mathrm{O}_{9}$ & Negative & 347.13475 & 4.72 & 347.13461 & - & - \\
\hline 6 & Loganic acid* & $\mathrm{C}_{16} \mathrm{H}_{24} \mathrm{O}_{10}$ & Negative & 375.12967 & 5.37 & 375.12974 & 5.37 & 375.12992 \\
\hline 7 & $1 \beta$-methoxylgardendiol & $\mathrm{C}_{10} \mathrm{H}_{14} \mathrm{O}_{5}$ & Negative & 213.07684 & 5.73 & 213.07636 & - & - \\
\hline 8 & Cistanoside $\mathrm{F}^{\star}$ & $\mathrm{C}_{21} \mathrm{H}_{28} \mathrm{O}_{13}$ & Negative & 487.14571 & 6.02 & 487.30565 & 5.94 & 487.07273 \\
\hline 9 & Gentiopicroside & $\mathrm{C}_{16} \mathrm{H}_{20} \mathrm{O}_{9}$ & Negative & 355.10345 & 6.39 & 355.10373 & - & - \\
\hline 10 & Caffeic acid* & $\mathrm{C}_{9} \mathrm{H}_{8} \mathrm{O}_{4}$ & Negative & 179.03498 & 7.19 & 179.03583 & 7.13 & 179.03406 \\
\hline 11 & 1ß-hydroxyl-4-epigardendiol & $\mathrm{C}_{11} \mathrm{H}_{16} \mathrm{O}_{5}$ & Negative & 227.09249 & 8.24 & 227.07684 & - & - \\
\hline 12 & Campneoside ॥ & $\mathrm{C}_{29} \mathrm{H}_{36} \mathrm{O}_{16}$ & Negative & 639.19305 & 9.89 & 639.19274 & 9.88 & 639.19316 \\
\hline 13 & Echinacoside* & $\mathrm{C}_{35} \mathrm{H}_{46} \mathrm{O}_{20}$ & Negative & 785.25096 & 10.16 & 785.25056 & 10.17 & 785.25104 \\
\hline 14 & Rutin* & $\mathrm{C}_{27} \mathrm{H}_{30} \mathrm{O}_{16}$ & Negative & 609.14610 & 11.20 & 609.14640 & - & - \\
\hline 15 & Arenarioside* & $\mathrm{C}_{34} \mathrm{H}_{44} \mathrm{O}_{19}$ & Negative & 755.24040 & 11.49 & 755.23968 & 11.48 & 755.24013 \\
\hline 16 & Cynaroside ${ }^{\star}$ & $\mathrm{C}_{21} \mathrm{H}_{20} \mathrm{O}_{11}$ & Negative & 447.09328 & 11.75 & 447.09342 & 11.76 & 447.12989 \\
\hline 17 & Rehmapicroside & $\mathrm{C}_{16} \mathrm{H}_{26} \mathrm{O}_{8}$ & Negative & 345.15549 & - & - & 11.84 & 345.15567 \\
\hline 18 & Verbascoside $^{\star}$ & $\mathrm{C}_{29} \mathrm{H}_{36} \mathrm{O}_{15}$ & Negative & 623.19814 & 12.14 & 623.19793 & 12.12 & 623.19875 \\
\hline 19 & 4-Coumaric acid* & $\mathrm{C}_{9} \mathrm{H}_{8} \mathrm{O}_{3}$ & Negative & 165.05462 & 12.37 & 165.05488 & 12.35 & 165.11338 \\
\hline 20 & Isoacteoside* & $\mathrm{C}_{29} \mathrm{H}_{36} \mathrm{O}_{15}$ & Negative & 623.19814 & 12.83 & 623.19793 & 12.91 & 623.19875 \\
\hline 21 & Apigenin-7-O- $\beta$-D-glucuronide & $\mathrm{C}_{21} \mathrm{H}_{20} \mathrm{O}_{10}$ & Negative & 431.09837 & 13.3 & 431.19252 & 13.27 & 431.09855 \\
\hline 22 & Tricin-7-O- $\beta$-D-glucuronide & $\mathrm{C}_{23} \mathrm{H}_{24} \mathrm{O}_{12}$ & Negative & 491.11949 & 13.76 & 491.15596 & 13.78 & 491.19275 \\
\hline 23 & Cistanoside C & $\mathrm{C}_{30} \mathrm{H}_{38} \mathrm{O}_{15}$ & Negative & 637.21379 & 13.83 & 637.10461 & 13.85 & 637.21399 \\
\hline 24 & Chrysoeriol-7-O- $\beta$-D-glucuronide & $\mathrm{C}_{22} \mathrm{H}_{22} \mathrm{O}_{11}$ & Negative & 461.10893 & 14.40 & 461.16673 & 14.32 & 461.14572 \\
\hline 25 & Jionoside C & $\mathrm{C}_{29} \mathrm{H}_{36} \mathrm{O}_{13}$ & Negative & 591.20831 & 14.69 & 591.07978 & 14.68 & 591.26153 \\
\hline 26 & Martynoside & $\mathrm{C}_{31} \mathrm{H}_{40} \mathrm{O}_{15}$ & Negative & 651.22944 & 16.02 & 651.19323 & 16.03 & 651.19342 \\
\hline 27 & Luteolin* & $\mathrm{C}_{15} \mathrm{H}_{10} \mathrm{O}_{6}$ & Negative & 285.04046 & - & - & 16.64 & 285.04056 \\
\hline 28 & Apigenin* & $\mathrm{C}_{15} \mathrm{H}_{10} \mathrm{O}_{5}$ & Negative & 269.04554 & 18.94 & 269.04461 & 18.93 & 269.04565 \\
\hline 29 & Tricin* & $\mathrm{C}_{17} \mathrm{H}_{14} \mathrm{O}_{7}$ & Negative & 329.06667 & 19.45 & 329.08803 & 19.44 & 329.23330 \\
\hline 30 & Chrysoeriol $^{\star}$ & $\mathrm{C}_{16} \mathrm{H}_{12} \mathrm{O}_{6}$ & Negative & 299.05611 & 19.55 & 299.07734 & 19.54 & 299.05626 \\
\hline
\end{tabular}

* Compared with standard compounds.

ethyl acetate extract was $114.263 \pm 0.255$ and $162.955 \pm 0.203$ $\mathrm{mg} / \mathrm{g}$, respectively.

\section{DISCUSSION}

Recently, Mongolian medicines have been more commonly used, owing to their low adverse effect; they also protect against and treat certain diseases. Furthermore, research on approaches that help explore the therapeutic value of natural pharmacotherapeutic agents has become a growing trend (Chester et al., 2017). C. daurica is widely used in traditional Mongolian medicine for the treatment of impetigo, psoriasis, pruritus, fetotoxicity, and diabetes. In spite of its tremendous therapeutic potential, complete chemical signature of $C$. daurica is unknown. Therefore, the aim of this study was to assess bioactivity and analyze chemical composition of $C$. daurica to lay a foundation to identify new drugs.

Based on the traditional therapeutic effect of $C$. daurica, the anti-inflammatory and $\alpha$-glucosidase-inhibitory activities of four polar $C$. daurica extracts were preliminarily evaluated to identify the active extracts. None of the tested samples exhibited cytotoxic effects at the effective concentrations (Figure 2). The n-butanol and ethyl acetate extracts showed pronounced inhibitory effects on LPS-induced NO production in RAW 264.7 cells compared with that of indomethacin (Table 1). Furthermore, the four extracts of $C$. daurica $(400 \mu \mathrm{g} / \mathrm{mL})$ used separately did not affect NO production in RAW 264.7 cells $(p>$ 0.05) (Figure 3). Activated macrophages release inflammatory mediators such as NO. The excessive production of inflammatory mediators in prolonged inflammation can cause cellular and tissue damage (Novilla et al., 2017). NO overproduction leads to cellular responses including apoptosis and necrosis (Nagai et al., 2003). To prevent the adverse effect of prolonged inflammation, anti-inflammatory agents are needed. Any substance that inhibits the production of these proinflammatory molecules is considered a potential antiinflammatory agent (Dinarello, 2010). Thus, the active extracts of $C$. daurica were n-butanol and ethyl acetate extracts.

In this study, the ethyl acetate extract significantly inhibited $\alpha$-glucosidase (with $\mathrm{IC}_{50}$ of $105.9 \pm 0.89 \mu \mathrm{g} / \mathrm{mL}$ ), and the $\alpha$ glucosidase-inhibition potency was equivalent to that of acarbose $(108.2 \pm 1.28 \mu \mathrm{g} / \mathrm{mL})$ (Table 2). n-Butanol presented the second highest inhibitory activity, with the $\mathrm{IC}_{50}$ value of $133.2 \pm 2.59 \mu \mathrm{g} /$ $\mathrm{mL}$. The therapeutic action of $C$. daurica extracts can be attributed to their inhibition activity against $\alpha$-glucosidase, thus reducing postprandial hyperglycemia and controlling diabetes. Acarbose is an inhibitor of carbohydrate digesting enzyme used to decrease glucose absorbance, but it has some 
A

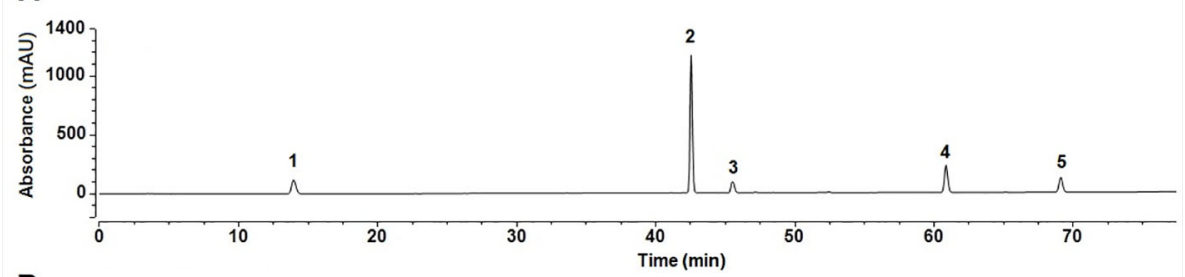

B

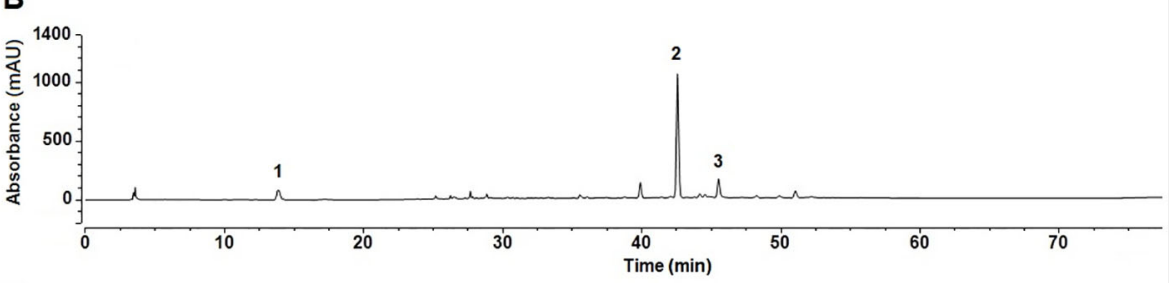

C

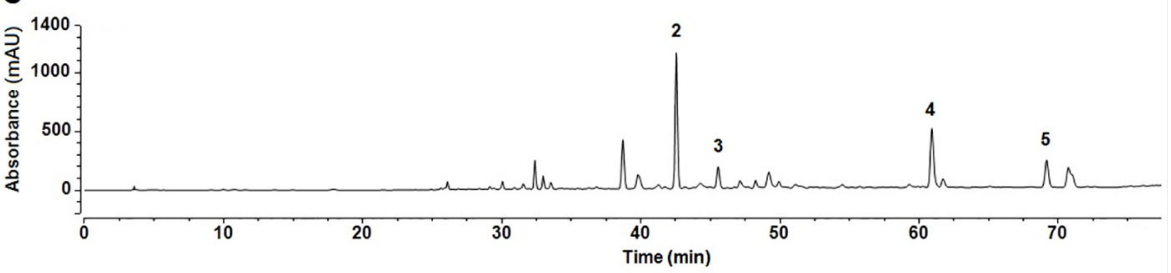

FIGURE 6 | The fingerprints of the five compounds in different extracts of $C$. daurica. (A) Mixed standard. (B) n-butanol extract. (C) ethyl acetate extract. 1 catalpol; 2 verbascoside; 3 isoacteoside; 4 luteolin; 5 apigenin.

TABLE 4 | Calibration curve for five compounds.

\begin{tabular}{lccc}
\hline Compound & Calibration curve $^{\mathbf{a}}$ & $\mathbf{R}^{\mathbf{2}}$ & Linear range $(\boldsymbol{\mu g} \mathbf{g} \mathbf{m L})$ \\
\hline Catalpol & $\mathrm{y}=45.201 \mathrm{x}+0.6434$ & 0.9997 & $0.472-2.832$ \\
Verbascoside & $\mathrm{y}=264.5 \mathrm{x}+28.613$ & 0.9991 & $0.346-2.076$ \\
Isoacteoside & $\mathrm{y}=636.89 \mathrm{x}+0.5168$ & 0.9998 & $0.022-0.132$ \\
Luteolin & $y=1123.9 x+0.538$ & 0.9995 & $0.028-0.168$ \\
Apigenin & $y=1083.6 \mathrm{x}+0.2633$ & 0.9995 & $0.018-0.108$ \\
\hline
\end{tabular}

${ }^{a} y=$ peak area and $x=$ concentration $(\mu g / m L)$. gastrointestinal adverse effects (Di Carli et al., 2003). Mongolian medicines can inhibit carbohydrate-metabolizing enzymes; due to their almost no adverse effect, studies have focused on $C$. daurica extracts as new $\alpha$-glucosidase natural inhibitors.

The separation and identification of $n$-butanol and ethyl acetate extracts from $C$. daurica yielded 10 compounds, namely, catalpol, vanillic acid, ajugol, cistanoside F, echinacoside, arenarioside, verbascoside, isoacteoside, apigenin, and tricin (Figure 4). Among them, vanillic acid, cistanoside F,

TABLE 5 | Precision, repeatability, and stability of five compounds (RSD\%, $n=5)$.

\begin{tabular}{|c|c|c|c|c|c|}
\hline Compound & Precision RSD & $\begin{array}{l}\text { Repeatability RSD } \\
\text { (n-butanol extract) }\end{array}$ & $\begin{array}{c}\text { Repeatability RSD } \\
\text { (Ethyl acetate extract) }\end{array}$ & $\begin{array}{c}\text { Stability RSD } \\
\text { (n-butanol extract) }\end{array}$ & $\begin{array}{c}\text { Stability RSD } \\
\text { (Ethyl acetate extract) }\end{array}$ \\
\hline Catalpol & 0.09 & 0.31 & - & 1.71 & - \\
\hline Verbascoside & 0.89 & 0.33 & 1.32 & 0.37 & 0.84 \\
\hline Isoacteoside & 0.15 & 0.53 & 1.35 & 0.61 & 0.48 \\
\hline Luteolin & 0.59 & - & 0.97 & - & 1.02 \\
\hline Apigenin & 0.43 & - & 1.93 & - & 1.12 \\
\hline
\end{tabular}

TABLE 6 | Quantitative analytical results of n-butanol extract and ethyl acetate extract form the $C$. daurica $(\mathrm{mg} / \mathrm{g}, \mathrm{n}=3, \mathrm{x} \pm \mathrm{s})$.

\begin{tabular}{|c|c|c|c|c|c|}
\hline Extract fractions & Catalpol & Verbascoside & Isoacteoside & Luteolin & Apigenin \\
\hline n-butanol extract & $113.918 \pm 0.127$ & $114.263 \pm 0.255$ & $9.475 \pm 0.059$ & - & - \\
\hline Ethyl acetate extract & - & $162.955 \pm 0.203$ & $15.967 \pm 0.021$ & $27.701 \pm 0.026$ & $14.079 \pm 0.004$ \\
\hline
\end{tabular}


echinacoside, arenarioside, verbascoside, isoacteoside, and tricin were isolated in C. daurica for the first time. Previous phytochemical reports described that the main chemical constituents in C. daurica are flavonoids and iridoids (Li et al., 2014; Bai et al., 2018). The present study demonstrated for the first time that $C$. daurica contains phenylethanoid glycosides. Based on these results, 30 compounds in n-butanol and ethyl acetate extracts of $C$. daurica were determined by UHPLC-QExactive (Figure 5 and Table 3). The results further proved that the main chemical constituents in C. daurica included phenylethanoid glycosides, flavonoids, and iridoids. In addition, this novel HPLC method was subsequently used for the simultaneous identification of five compounds (catalpol, verbascoside, isoacteoside, luteolin, and apigenin) with high content and potential activity in the n-butanol and ethyl acetate extracts of $C$. daurica (Figure 6, Table 4, and Table 5). It is worth noting that the content of verbascoside in the nbutanol and ethyl acetate extracts of $C$. daurica was very high, that is, $114.263 \pm 0.255$ and $162.955 \pm 0.203 \mathrm{mg} / \mathrm{g}$, respectively (Table 6). This study provided a chemical basis for the further development and utilization of $C$. daurica.

The anti-inflammatory and anti-diabetic activities of $C$. daurica can be attributed to the bioactive compounds. Phenylethanoid glycosides, flavonoids, and iridoids exhibit extensive pharmacological activities, including antiinflammatory (Hanfer et al., 2017; Spagnuolo et al., 2018; Zhang et al., 2018) and anti-diabetic activities (Miura et al., 1996; Semaan et al., 2017). Verbascoside has been the subject of biological studies demonstrating anti-inflammatory activity in several models, such as the intestinal inflammation model, where it decreased the presence of pro-inflammatory molecules (Carrillo-Ocampo et al., 2013). Previous studies have shown that verbascoside downregulates some pro-inflammatory signal transduction pathways by increasing the activity of tyrosine phosphatase SHP-1 in U937 cell line (Pesce et al., 2015). Furthermore, studies have reported that intravenous injection of catalpol exhibited anti-hyperglycemic activity in a dosedependent manner in streptozotocin-induced diabetic rats representing insulin-dependent diabetes mellitus (Huang et al., 2010). Therefore, the development of anti-inflammatory and anti-diabetic drugs from $C$. daurica has considerable advantages. However, understanding the mechanisms underlying the antiinflammatory and anti-diabetic activities of $C$. daurica needs more studies in vitro and in vivo. Further studies are also needed to identify the anti-inflammatory and anti-diabetic compounds,

\section{REFERENCES}

Amessis-Ouchemoukh, N., Abu-Reidah, I. M., Quirantes-Piné, R., RodríguezPérez, C., Madani, K., Fernández-Gutiérrez, A., et al. (2014). Tentative characterisation of iridoids, phenylethanoid glycosides and flavonoid derivatives from Globularia alypum L. (Globulariaceae) leaves by LC-ESIQTOF-MS. Phytochem. Analysis. 25, 389-398. doi: 10.1002/pca.2506

Andary, C., Privat, G., Wylde, R., and Heitz, A. (1985). Pheliposide et arenarioside, deux nouveaux esters heterosidiques de l'acide cafeique isoles de Orobanche arenaria. J. Nat. Prod. 48 (5), 778-783. doi: 10.1021/ np50041a010 and to deeply comprehend the mechanism of action of the active compounds in n-butanol and ethyl acetate extracts of $C$. daurica.

In conclusion, the results of our study showed that phenylethanol-glycoside compounds are important components of $C$. daurica. These findings support the antiinflammatory and anti-diabetic activities of $C$. daurica and indicate that $C$. daurica could be utilized as a potential source of novel anti-diabetic and anti-inflammatory agents.

\section{DATA AVAILABILITY STATEMENT}

The raw data supporting the conclusions of this article will be made available by the authors, without undue reservation, to any qualified researcher.

\section{AUTHOR CONTRIBUTIONS}

ML and CZ: Conceived and designed the experiment, analysis and interpretation of data, and critical evaluation of manuscript. XG: literature review, experimental studies, data collection, and manuscript preparation. JW, MeZ, PW, CW, RS, EZ, and MiZ: literature review, experimental studies. All authors read and approved the final version of the manuscript.

\section{FUNDING}

This work was supported by the National Natural Science Foundation of China (grant no. 81760776), the National Natural Science Foundation of China (grant no. 81874336), the Natural Science Foundation of Inner Mongolia Autonomous Region (grant no. 2018ZD13), the China Agriculture Research System (grant no. CARS-21), the 2018 Chinese medicine public health service subsidy special "the fourth survey on Chinese materia medica resource" (grant no. Finance Society [2018] 43).

\section{SUPPLEMENTARY MATERIAL}

The Supplementary Material for this article can be found online at: https://www.frontiersin.org/articles/10.3389/fphar.2020. 00048/full\#supplementary-material

Bai, C. L., Wang, Q. H., Xu, Y. H., Han, J. S., and Bao, Y. P. (2018). The isolation and structural elucidation of a new iridoid glycoside from Cymbaria dahurica L. Z Naturforsch. 73, 377-379. doi: 10.1515/znb-2017-0205

Bao, Y. F., Shen, X., and Wang, C. F. (2018). The research progress and development prospects of biosynthesis, structure activity relationship and biological activity of caffeic acid and its main types of derivatives. Nat. Prod. Res. Dev. 30, 1825-1833, 1733. doi: 10.16333/j.1001-6880.2018.10.028

Carrillo-Ocampo, D., Bazaldúa-Gómez, S., Bonilla-Barbosa, J., Aburto-Amar, R., and Rodríguez-López, V. (2013). Anti-inflammatory activity of iridoids and verbascoside isolated from castilleja tenuiflora. Molecules 18, 12109-12118. doi: 10.3390/molecules 181012109 
Chang, Y. Q., Li, M. H., Jiang, S., Han, H. R., and Zhang, C. H. (2015). Effect of the extracts from Cymbariae on the blood glucose levels in alloxan-induced diabetic mice. J. Baotou Med. Coll. 5, 6-7. doi: 10.16833/ j.cnki.jbmc.2015.05.004

Chen, Z. 1., Shi, Y. P., Zhong, X. T., and Yao, Q. Q. (2011). Chemical constituents in dried inflorescence of Aster souliei (II). Chin Tradit. Herbal. Drugs 42, 42-45. doi: 0253-2670(2011)01-0042-04

Cheng, J., Yi, X., Chen, H., Wang, Y., and He, X. (2017). Anti-inflammatory phenylpropanoids and phenolics from Ficus hirta Vahl. Fitoterapia 121, 229-234. doi: 10.1016/j.fitote.2017.07.018

Chester, K., Paliwal, S., Khan, W., and Ahmad, S. (2017). UPLC-ESI-MS/MS and HPTLC method for quantitative estimation of cytotoxic glycosides and aglycone in bioactivity guided fractions of Solanum nigrum L. Front. Pharmacol. 8, 1-15. doi: 10.3389/fphar.2017.00434

Chu, C. J., Li, X. L., Xia, L., Zhang, J., and Chen, D. F. (2014). Chemical constituents in leaves of Vaccinium bracteatum and their anti-complementary activity. Chin Tradit. Herbal. Drugs 45, 458-465. doi: 10.7501/j.issn.0253-2670.2014.4.002

Di Carli, M. F., Janisse, J., Ager, J., and Grunberger, G. (2003). Role of chronic hyperglycemia in the pathogenesis of coronary microvascular dysfunction in diabetes. J. Am. Coll. Cardiol. 41, 1387-1393. doi: 10.1016/S0735-1097(03) 00166-9

Dinarello, C. A. (2010). Anti-inflammatory agents: present and future. Cell 140, 935-950. doi: 10.1016/j.cell.2010.02.043

Dong, Z., and Chen, C. X. (2013). Progress in the research of pharmacology of catalpol. Chin Tradit. Pat. Med. 35, 1047-1051. doi: 10.3969/j.issn.10011528.2013.05.044

Guo, J. J., liu, H., Zhu, H. Y., Ren, J. X., and Liang, Y. H. (2017). Study on antiinflammatory and analgesic effects of mongolian medicine Cymbaria dahurica extract. Chin Pharm. 28, 64-67. doi: 10.6039/j.issn.1001-0408.2017.01.17

Han, H., Shan, Q., Zhou, F. J., Liu, J. Y., and Hou, W. B. (2013). Chemical constituents in Epimedium sagittatum and their in vitro antitumor activities. Drugs Clin. 28, 269-273. doi: 10.7501/j.issn.1674-5515.[year].[issue].[sequence]

Han, M. F., Zhang, L. Q., and Li, Y. M. (2017). Research progress on chemical structures and pharmacological effects of natural aucubin and its derivatives. Chin Tradit. Herbal. Drugs 48, 4105-4113. doi: 10.7501/j.issn.02532670.2017.19.031

Hanfer, M., Cheriet, T., Ameddah, S., Mancini, I., Seghiri, R., Menad, A., et al. (2017). Iridoids and anti-inflammatory properties of n-butanol extract of Linaria tingitana Boiss. \& Reut. Nat. Prod. Res. 31, 2008-2015. doi: 10.1080/ 14786419.2016 .1272111

Health department of Inner Mongolia autonomous region (1987). "Standard of Mongolian medicinal materials in inner Mongolia," (China: Inner Mongolia Science and Technology Press).

$\mathrm{Hu}, \mathrm{S}$. L. (2018). The modern research progress of mongolian medicine cymbaria dahurica L. Chin J. Ethnomed. Ethnopharm. 27, 31-32,39. doi: 1007-8517 (2018)13-0031-02

Huang, W. J., Niu, H. S., Lin, M. H., Cheng, J. T., and Hsu, F. L. (2010). Antihyperglycemic effect of catalpol in streptozotocin-induced diabetic rats. J. Nat. Prod. 73, 1170-1172. doi: 10.1021/np9008317

Jeong, H. J., Nam, S. Y., Kim, H. Y., Jin, M. H., Kim, M. H., Roh, S. S., et al. (2017). Anti-allergic inflammatory effect of vanillic acid through regulating thymic stromal lymphopoietin secretion from activated mast cells. Nat. Prod. Res. 32, 1-5. doi: 10.1080/14786419.2017.1389938

Li, M. H., Li, Y., Wang, Z. W., Cui, Z. H., Huang, L. Q., and Xiao, P. G. (2012). Ethnopharmacological survey of medicinal plants in baotou, Inner Mongolia, China. Chin Herb. Med. 4, 301-313. doi: 10.3969/j.issn.1674-6348.2012.04.007

Li, Z. H., Long, P., Bai, S., Yang, D. W., Zhu, H., Cui, Z. H., et al. (2014). Chemical constituents from Cymbaria dahurica L. (Scrophulariaceae). Biochem. Syst. Ecol. 57, 11-14. doi: 10.1016/j.bse.2014.07.012

Li, Y., Hong, L., Liu, C., and Tang, J. M. (2017). Research progress on the pharmacological effects of echinacoside. Her. Med. 36, 56-60. doi: 10.3870/ j.issn.1004-0781.2017.01.014

Li, H. X., Zhang, Q., Liu, Y. N., Liu, P., Wang, L. Y., Li, D. N., et al. (2018a). Comparative study on anti-inflammatory activity of luteolin and luteoloside. J. Yantai Unive. 31, 114-120. doi: 10.13951/j.cnki.37-1213/n.2018.02.004

Li, Y., Yu, H., Jin, Y., Li, M., and Qu, C. (2018b). Verbascoside alleviates atopic dermatitis-like symptoms in mice via its potent anti-inflammatory effect. Int. Arch. Allerg. Immunol. 175, 220-230. doi: 10.1159/000486958
Li, Y. S. (2013). Progress on resources, pharmacological effect and major forms of rutin. Amino Acids Biotic Resour. 35, 13-16. doi: CNKI:SUN:AJSH.0.2013-03005

Liang, Y. H., Liang, J., Yao, H. Y., Liu, H., and Li, D. W. (2016). Advances in studies on the chemical constitutes in Xinba and their pharmacological activites. Lishizhen Med. Mater Med. Res. 27, 1201-1204. doi: 10.3969/ j.issn.1008-0805.2016.05.071

Liu, P., Yang, Y. L., Deng, X. R., Zhao, T. Z., and Yin, W. P. (2011). Studies on Chemical Constituents of Glycosides from Syringa pubenscens. Chin. J. Exp. Tradit. Med. Formulae. 17, 127-131. doi: 10.13422/j.cnki.syfjx.2011. 19.050

Liu, Y. F., Shi, G. R., Wang, X., Zhang, C. L., Wang, Y., Chen, R. Y., et al. (2016). Chemical constituents from whole plants of Rehmannia chingii. Chin Tradit. Herbal. Drugs 47, 1830-1833. doi: 10.7501/j.issn.0253-2670.2016. 11.002

Miura, T., Nishiyama, Y., Ichimaru, M., Moriyasu, M., and Kato, A. (1996). Hypoglycemic activity and structure-activity relationship of iridoidal glycosides. Biol. Pharm. Bull. 19, 160-161. doi: 10.1248/bpb.19.160

Nagai, H., Kumamoto, H., Fukuda, M., and Takahashi, T. (2003). Inducible nitric oxide synthase and apoptosis-related factors in the synovial tissues of temporomandibular joints with internal derangement and osteoarthritis. J. Maxil Surg. 61, 801-807. doi: 10.1016/S0278-2391(03)00155-1

Nguyen, A. T., Fontaine, J., Malonne, H., Claeys, M., Luhmer, M., and Duez, P. (2005). A sugar ester and an iridoid glycoside from Scrophularia ningpoensis. ChemInform 36, 1186. doi: 10.1002/chin.200544210

Novilla, A., Djamhuri, D. S., Nurhayati, B., Rihibiha, D. D., Afifah, E., and Widowati, W. (2017). Anti-inflammatory properties of oolong tea (Camellia sinensis) ethanol extract and epigallocatechin gallate in LPS-induced RAW 264.7 cells. Asian Pac. J. Trop. Bio. 7, 1005-1009. doi: 10.1016/ j.apjtb.2017.10.002

Pesce, M., Franceschelli, S., Ferrone, A., De Lutiis, M. A., Patruno, A., Grilli, A., et al. (2015). Verbascoside down-regulates some pro-inflammatory signal transduction pathways by increasing the activity of tyrosine phosphatase SHP-1 in the U937 cell line. J. Cell Mol. Med. 19, 1548-1556. doi: 10.1111/ jcmm. 12524

Pharmacopoeia committee of the ministry of health of the People's Republic of China (1998). Pharmaceutical standard of the ministry of health of the people republic of China (Mongolian medicine standard). China: People's Medical Publishing House.

Qiao, S., Li, W., Tsubouchi, R., Haneda, M., Murakami, K., Takeuchi, F., et al. (2005). Rosmarinic acid inhibits the formation of reactive oxygen and nitrogen species in RAW 264.7 macrophages. Free Radical Res. 39, 995-1003. doi: 10.1080/ 10715760500231836

Schmidt, J. S., Nyberg, N. T., and Staerk, D. (2014). Assessment of constituents in Allium by multivariate data analysis, high-resolution $\alpha$-glucosidase inhibition assay and HPLC-SPE-NMR. Food Chem. 161, 192-198. doi: 10.1016/ j.foodchem.2014.03.062

Semaan, D. G., Igoli, J. O., Young, L., Marrero, E., Gray, A. I., and Rowan, E. G. (2017). In vitro anti-diabetic activity of flavonoids and pheophytins from Allophylus cominia Sw. on PTP1B, DPPIV, alpha-glucosidase and alphaamylase enzymes. J. Ethnopharmacol. 203, 39-46. doi: 10.1016/ j.jep.2017.03.023

Song, Q. Q., Zhao, Y. F., Zhang, N., Zhang, Q., Liu, Y., Li, J., et al. (2016). Establishment of HPLC fingerprint of Rehmanniae Radix and its HPLC-ESIMS analysis. Chin Tradit. Herb. Drugs 47, 4247-4252. doi: 10.7501/j.issn.02532670.2016.23.022

Spagnuolo, C., Moccia, S., and Russo, G. L. (2018). Anti-inflammatory effects of flavonoids in neurodegenerative disorders. Eur. J. Med. Chem. 153, 105-115. doi: 10.1016/j.ejmech.2017.09.001

Sun, B., Qu, W. J., and Zhang, X. L. (2004). Progress in the research of pharmacology of apigenin. J. Chin Med. Mater. 27, 531-534. doi: 10.13863/ j.issn1001-4454.2004.07.032

Wang, Z. P., Chu, Y. J., Zhang, Y. Y., Chen, Y., Zhang, J., and Chen, X. (2018). Investigation of potential toxic components based on the identification of Genkwa Flos chemical constituents and their metabolites by high-performance liquid chromatography coupled with a Q Exactive high- resolution benchtop quadrupole Orbitrap mass spectrometer. J. Sep Sci. 41, 3328-3338. doi: 10.1002/ jssc.201800424 
Wu, J., Zhou, X. L., Zhou, X. L., Huang, S., and Wang, C. J. (2012). Chemical constituents from flowers of Incarvillea younghusbandii. Chin Tradit. Herbal. Drugs 43, 55-59. doi: 10.7666/d.y2108516

Yang, L. J., Wang, D. D., Zhang, Y. F., Wu, H. J., Chen, D. Z., and Shi, L. (2017). Research progress on luteoloside in Lonicerae Japonicae Flos. Chin Med. Her. 14, 58-61. doi: 1673-7210(2017)08(c)-0058-04

Yin, Y. T., Liu, L. L., and Liu, L. Y. (2017). Tricin's inhibitory effects on TLR4/ MyD88/NF- $\kappa B$ pathway of alveolar macrophages in asthma mice. Chin Tradit. Pat. Med. 39, 450-454. doi: 10.3969/j.issn.1001-1528.2017.03.002

Zhang, C. H., Xia, Y., Hasi, B. T. R., Hu, Y. L., Li, Z. H., and Wu, G. D. (2013). Research progress of Mongolian xinba. Mod. Chin Med. 15, 1068-1072. doi: 10.13313/j.issn.1673-4890.2013.12.005

Zhang, C. H., Zhao, Z. Y., Hasibateer, Li, Z. H., Wu, M. M., Zou, D. Z., et al. (2015). Mongolian folk medicine-from traditional practice to scientific development. Chin J. Chin Mat. Med. 40, 2492-2495. doi: 10.4268/ cjcmm20151304

Zhang, J., Pang, D. R., Li, Y. T., Zhen, J., Zhang, Q., Zhao, Y. F., et al. (2016a). Chemical Constituents from the Whole Plants of Lagopsis supina. Chin Pharm. J. 51, 2005-2008. doi: CNKI:SUN:ZGYX.0.2016-23-004

Zhang, Y. B., Jiang, Z. Z., Wang, Y. F., Yang, L., Yang, F., and Yu, H. J. (2016b). Analysis of chemical constituents in fresh, dried and prepared Rehmanniae Radix by UPLC/
ESI-Q-TOF MS. Chin Tradit. Pat. Med. 38, 1104-1108. doi: 10.3969/j.issn.10011528.2016.05.029

Zhang, Y., Wang, K., Chen, H., He, R., Cai, R., Li, J., et al. (2018). Antiinflammatory lignans and phenylethanoid glycosides from the root of Isodon ternifolius (D.Don) Kudô. Phytochemistry 153, 36-47. doi: 10.1016/ j.phytochem.2018.05.017

Zhen, X. P., and Shi, J. G. (2004). Chemical constituents from whole plants of Lagotis brevituba. Chin Tradit. Herbal. Drugs 5, 27-28. doi: 10.7501/ j.issn.0253-2670.2004.5.210

Conflict of Interest: The authors declare that the research was conducted in the absence of any commercial or financial relationships that could be construed as a potential conflict of interest.

Copyright (c) 2020 Gong, Wang, Zhang, Wang, Wang, Shi, Zang, Zhang, Zhang and Li. This is an open-access article distributed under the terms of the Creative Commons Attribution License (CC BY). The use, distribution or reproduction in other forums is permitted, provided the original author(s) and the copyright owner(s) are credited and that the original publication in this journal is cited, in accordance with accepted academic practice. No use, distribution or reproduction is permitted which does not comply with these terms. 